that unemployment insurance can do no more than offer a temporary palliative, and that the experience of England and Germany shows all too clearly the limitations from which it suffers. Likewise public works, though necessary to relieve immediate distress, are of but temporary advantage. This is true even of the multiplication of resources provided by schemes of such magnitude as the draining of the Pontine Marshes or the reclamation of the Zuider Zee. The fundamental problem is to secure a stable balance between production, consumption and population. In this connexion, the biological ageing of a population must necessarily have economic repercussions, European South Africa is still demographically some twenty-five years behind England, but South Africa is also ageing. He suggests as a solution for South Africa's problems, a vigorous policy of immigration, and points out that so long as America keeps an open door, her unemployment difficulties are not very serious. There remains, he adds, an alternative way of controlling the contraction of South Africa's market, and that is by enhancing the purohasingpower of the non-European population.

\section{Cultivation of Onions}

A NEw bulletin (No. 69) recently issued by the Ministry of Agriculture (H.M. Stationery Office, 1s.) deals with onions and related crops. Considering that more than 90 per cent of the onions consumed in Great Britain are purchased from abroad at an annual cost of nearly 2 million pounds, it is evident that this is an instance of a crop which could with advantage be much more extensively grown in this country. The acreage devoted to onion growing in England and Wales has seriously declined since 1913, the reduction in some instances amounting to 50 or even 75 per cent. The soil in many parts of the country is eminently suited to the crop, and although a certain degree of skill is required in cultivation, manuring, harvesting and storing, there seems no reason why onion production should not be substantially increased. Besides the wealth of practical information provided in the bulletin, interesting comparisons are drawn between the methods of cultivation employed in the principal onion-growing countries such as Spain, Holland, Egypt and the United States, and the respective seasons at which their produce is imported into Great Britain.

\section{Air-Speed Record}

IT is announced by the Milan correspondent of the Times that Warrant Officer Francesco Agello, flying at Desenzano, on Lake Garda, on October 23, attained an average speed of $709 \cdot 202$ kilometres (440.67 miles) an hour, and a maximum speed on one run of 711 kilometres (441.22 miles) an hour. Agello was flying a Macchi-Castoldi 72 seaplane with a Fiat engine similar to that in which he set up a record on April 10 last year of 682.4 kilometres an hour.

\section{Announcements}

WE regret to announce the death of Prof. Santiago Ramón y Cajal, For.Mem.R.S., professor of histology and pathological anatomy in the University of Madrid, on October 18, at the age of eighty-two years.

A Discussion on the John Murray Expedition will be held at the Royal Society on November 1 at 4.30, to be opened by Lieut.-Col. R. B. Seymour Sewell. Preliminary accounts of the work of the Expedition have appeared in NATURE of January 20, p. 86, and May 5, p. 669.

IT is announced that Mr. J. M. Edmonds has been appointed geologist on the staff of the Geological Survey, Khartoum, Anglo-Egyptian Sudan.

AT the annual statutory meeting of the Royal Society of Edinburgh held on October 22, the following officers were elected : President : Prof. D'Arcy W. Thompson; Vice-Presidents : Sir Thomas Holland, Prof. C. G. Darwin, Prof. R. A. Sampson, Principal O. Charnock Bradley, Prof. P. T. Herring, the Marquis of Linlithgow; General Secretary: Prof. J. H. Ashworth; Secretaries to Ordinary Meetings : Prof. F. A. E. Crew and Prof. J. P. Kendall; Treasurer: Dr. James Watt; Curator of Library and Museum: Dr. Leonard Dobbin.

THE beautifully illustrated and printed Natur und Volk, published in Frankfurt, is mainly for popular reading. The August number contains, in addition to botanical and geological articles, papers on the work of Canadian beavers and on abnormalities in the teeth of rodents, both informative and with good photographs.

APPLICATIONs are invited for the following appoint ments, on or before the dates mentioned :-A lecturer in mathematics at the Borough Polytechnic, Borough Road, London, S.E.1-The Principal (Nov. 1). A headmaster of the Junior Technical School, Acton Technical College-The Secretary, 10 Great George Street, Westminster, S.W.1 (Nov. 3). A director of the New Art Gallery and Museum, Perth -The Town Clerk, City Chambers, Perth (Nov. 3). An examiner in the Aeronautical Inspection Directorate-The Secretary (S.2), Air Ministry, Adastral House, Kingsway, W.C.2 (Nov. 5). An assistant professor of gunnery and mathematics at the Military College of Science, Red Barracks, Woolwich, S.E.18 (Nov. 12). A director of research at the Wool Industries Research Association, Torridon, Headingley, Leeds, 6-The Secretary (Nov. 15). A physiologist at the Marine Biological Laboratory, PlymouthThe Director (Nov. 19). A professor of modern experimental physics at the National Central University, Nanking, and a professor of hydraulic engineering at the National Chekiang University, Hangchow, China-The Universities China Committee, 91, Gower Street, W.C.1. An advisory entomologist at the Harper Adams Agricultural College, Newport, Shropshire-The Principal. Two assistants in the Directorate of Technical Development, Royal Aircraft Establishment, South Farnborough, Hants. 